\title{
PRELIMINARY TRIALS FOR MORE PRODUCTION OF MALE OFFSPRINGS AND IMPROVEMENT OF GROWTH AND REPRODUCTIVE PERFORMANCE IN RATS
}

\author{
ROFAIIL, S. K. AND A. M. H. AZAB \\ Veterinary Serum and Vaccine Research Institute, ARC, Ministry of Agriculture, \\ Abbasia, Cairo
}

(Manuscript received 5 March 2009)

\begin{abstract}
The effect of ethinyl estradiol was investigated on reproduction and growth performance of rats and more production of males which are characterized by high growth rate to meet the increased demand for male rats for medical researches. Ethinyl estradiol was supplemented at level of $50 \mathrm{mg} / \mathrm{kg}$ ration for feeding rats for 6 weeks before mating. The study was carried out on 2 parities together with control groups. The results showed high reproductive activity in treated groups with improvement of reproductive performance and increasing numbers of males and pregnant females. The number of embryos per female, growth rate of new born increased, and preweaning mortalities decreased. The number of viable foeti and baby weight increased without deformation. The second parity showed better improvement in all studied parameters in comparison with first parity. It can be concluded that supplementation of ethinyl estradiol to rats ration has a significant role in improving the reproductive parameters and growth performance.
\end{abstract}

\section{INTRODUCTION}

Rats had rapidly become most important laboratory animals used for several scientific researches. The main requirement to rats production is the improvement of reproductive and growth performance. Production of male rats used in medical researches is of great importance, specially those about the physiological status of animals, in addition to their character of high growth rate (James et al., 2002). Nutrition has a profound effect on growth and health of animals. The nutrition deficiencies impair the immune responsiveness, and thereby increase mortality, subsequently the production capacity (Harkness and Wagner, 1995).

Estrogen is mainly synthesized by the ovaries and play an indispensable role for reproductive regulation in mammals including rats (Turgeon, 1979). Oestradiol is also present in low concentration in serum of normal males, approximately one third is secreted by testis, while the remainder content is derived from zona reticularis of the adrenal cortex, as well as during metabolism of testosterone in the liver and adipose tissue (Marshall, 1988). 
Supplementation of ethinyl estradiol to rats feed was studied in order to produce high percentage of males, and to improve the reproduction performance (Hafez, 2000). Several studies were performed to explore the effect of oestrogen on several parameters in rats (Mabrouk et al., 1993). The aim of the present study was to throw light on possible effect of ethinyl estradiol supplementation on pregnancy, gestation period, offsprings of rats and number of male rats.

\section{MATERIALS AND METHODS}

\section{1- Experimental animals}

The study was carried out on one hundred and sixty rats; they were divided into two groups, each of which contained sixty females, and twenty ones were males. They were kept and bred under controlled room temperature of $22^{\circ} \mathrm{C} \pm 1$, a relative humidity of $45 \pm 5 \%$ and light/dark cycle of $10 / 14$ hours, feed and water were afforded ad libitum.

\section{2- Ethinyl estradiol}

It was obtained from Kahira Company for Pharmaceutical Industries, Cairo, and was added to rats ration at a concentration of $50 \mathrm{mg} / \mathrm{kg}$ according to Marshall (1988).

\section{3- Experimental design}

3.1. The first group of rats consumed ration supplemented with $50 \mathrm{mg} / \mathrm{kg}$ ethinyl estradiol for 6 weeks, the second group of rats were kept as control group consuming ration without ethinyl estradiol supplementation.

3.2. After the period of treatment of the first group ( 6 weeks), each 2 females were caged together with one male. The females were examined every morning for the presence of vaginal plug, the day the plug was detected was considered as day 0 of gestation and the pregnant females were placed in separate cages (McGuire et al., 1992).

3.3. The gestation period for each pregnant female and the number of pregnant female rats were recorded.

3.4. On day 17 of gestation, some pregnant females were killed by cervical dislocation, the abdominal wall of each female was opened and both uterine horns were promptly exposed to their full extent. The number of resorbed and intact fetuses were counted and recorded. The uterine horns were then opened to determine the number of live and dead fetuses. Spontaneous movement, reddish colour, size and or movement induced with a forceps on the neck or the head of fetus were the criteria used to distinguish between alive and dead fetuses; also, detection of any abnormalities were recorded. 
3.5. The litter weight at birth, 10th day, and 20th day after birth and number of litters per each female were recorded.

3.6. On $21^{\text {st }}$ day (age of weaning), the weaned rats were sexed and the number of males and females were recorded. The litter weight and the mortalities of the pups till weaning were recorded.

3.7. The weaned rats (females and males) consumed ethinyl estradiol in their ration for 6 weeks, then mating occurred, and the same previous steps were followed and considered as second parity group.

\section{RESULTS AND DISCUSSION}

The reproductive parameters as affected by ethinyl estradiol are shown in Table 1 , from which it is clear that the number of pregnant females increased and the gestation length became shorter in rats supplemented with ethinyl estradiol in their ration. These results are in agreement with those of Heneweer et al. (2007) who reported that estradiol administration led to a significant improvement of reproductive parameters.

The number of embryos per pregnant female was recorded, and the average number of males per total number of weaned rats was higher than females. The obtained results are in harmony with those mentioned by Desprez et al. (2003) who stated that functional sex reversal is most easily achieved through oral application of estrogens or androgen incorporated into the feed and administered during the period of sex differentiation.

The effect of ethinyl estradiol treatment in the ration of rats resulted in increased male numbers, and the same observation was obtained by Williams et al. (2001) using the same feminizing agent, however with lower doses to produce the same results.

The improvement in the second parity in any reproductive parameter, as shown in Table 2, may be due to the accumulating effect of the treatment with ethinyl estradiol which had a direct effect on reproduction. These findings are similar to those described by Gray et al. (1993). Table 3 showed the pups development and their growth from pregnant females supplemented with ethinyl estradiol in their ration. They revealed remarkable reduction in the number of dead foeti without any external or skeletal malformation, combining in a harmony with those reported by Heneweer et al. (2007).

The mortality per litter till weaning was reduced completely, with similar observations by Khalifa (2006) who reported that ethinyl estradiol was associated with a reduction in preweaning mortality per litter. 
The average live body weight has increased in rats fed ration with ethinyl estradiol at birth, after 10 days, and 20 days (at weaning), and this is in agreement with the findings of Wallace et al. (2004) who found that the addition of ethinyl estradiol had a remarkable effect on body weight. The improvement may be attributed to the established anabolic derive to maternal requirement of the gravid uterus. The same observations were recorded by Gray et al. (1993) who treated rats for 3 days with estradiol benzoate, ethinyl estradiol or either of the anti-estrogen, led to body weight gain, adipose tissue lipoprotein lipase activity and hepatic fatty acid synthetase activity. Srivastava et al. (2007) found that improvement of the growth and reproductive performance as a result of ethinyl estradiol treatment can be attributed to the increased animal health and the responsiveness of immune system besides the other functions being affected by growth performance.

Table 4 showed the improvement in the second parity in reproductive parameters as reduction in the number of dead young foeti with no abnormalities and the increase of average body weight of weaned rats. The same observations were recorded by Khalifa (2006).

It could be concluded that supplementation of ethinyl estradiol as feed additive to the ration of rats can improve the growth rate and reproductive performance.

Table 1. Reproductive parameters of rats fed a ration supplemented with ethinyl estradiol at first parity.

\begin{tabular}{|l|c|c|}
\hline \multicolumn{1}{|c|}{ Item } & Treated & Control \\
& group & group \\
\hline Number of pregnant female / number of females & $50 / 60$ & $37 / 60$ \\
\hline Average gestation length & 18 days & 21 days \\
\hline Average number of embryos / female & 10 & 6 \\
\hline Number of weaned males / total number of weaned rats & $340 / 500$ & $112 / 222$ \\
\hline Number of weaned females / total number of weaned rats & $160 / 500$ & $110 / 222$ \\
\hline
\end{tabular}

The total number of female rats were 60 in treated group and 60 in control group.

The total number of weaned rats were 500 in treated group and 222 in control group. 
Table 2. Reproductive parameters of rats fed on ration supplemented with ethinyl estradiol at second parity.

\begin{tabular}{|l|c|c|}
\hline \multicolumn{1}{|c|}{ Item } & Treated group & $\begin{array}{c}\text { Control } \\
\text { group }\end{array}$ \\
\hline Number of pregnant females / number of females & $55 / 60$ & $41 / 60$ \\
\hline Average gestation length & 17 days & 21 days \\
\hline Average number of embryos / female & 12 & 8 \\
\hline Number of weaned males / total number of weaned rats & $470 / 660$ & $168 / 328$ \\
\hline Number of weaned females / total number of weaned rats & $190 / 660$ & $160 / 328$ \\
\hline
\end{tabular}

The total number of female rats were 60 in treated group and 60 in control group The total number of weaned rats were 660 in treated group and 328 in control group.

Table 3. Pups development and growth from pregnant females supplemented with ethinyl estradiol in its ration at 1st parity.

\begin{tabular}{|l|c|c|}
\hline \multicolumn{1}{|c|}{ Item } & $\begin{array}{c}\text { Treated } \\
\text { group }\end{array}$ & $\begin{array}{c}\text { Control } \\
\text { group }\end{array}$ \\
\hline Average number of dead youngs / viable young per each pregnant female & $0 / 10$ & $1 / 6$ \\
\hline Abnormalities observed & None & ++ \\
\hline Postnatal mortality & None & + \\
\hline Average live body weight at birth per each female (gm) & 8 & 5 \\
\hline Average live body weight after 10 days per each female (gm) & 30 & 22 \\
\hline Average live body weight after 20 days (at weaning) per each female (gm) & 60 & 40 \\
\hline
\end{tabular}

Table 4. Pups development and growth from pregnant females supplemented with ethinyl estradiol in their ration at 2 nd parity.

\begin{tabular}{|l|c|c|}
\hline \multicolumn{1}{|c|}{ Item } & $\begin{array}{c}\text { Treated } \\
\text { group }\end{array}$ & $\begin{array}{c}\text { Control } \\
\text { group }\end{array}$ \\
\hline Average number of dead youngs / viable youngs per each pregnant female & $0 / 12$ & $1 / 8$ \\
\hline Abnormalities observed & None & + \\
\hline Postnatal mortality & None & + \\
\hline Average live body weight at birth per each female (gm) & 10 & 6 \\
\hline Average live body weight after 10 days per each female (gm) & 43 & 25 \\
\hline Average live body weight after 20 days (at weaning) per each female (gm) & 72 & 44 \\
\hline
\end{tabular}




\section{REFERENCES}

1. Desprez, D. E., M. C. Geraz, C. Hoareau, P. Basc and J. E. Broiller. 2003. Production of a high percentage of male offspring with a natural androgen: 11-Bhydroxy and restenedione (11B0HA4) in florida red tilapia. Aqua Culture, 216 (1): $55-65$.

2. Gray, J. M., S. Schrock and M. Bishop. 1993. Estrogens and antiestrogens: actions and interaction with fluphenazine on food intake and body weight in rats. Am.J. Physiology, 264 (6): 1214-1218.

3. Hafez, E. S. E. 2000. Reproduction in farm animals. 7th ed. Lea and Febiger, Washington Square, Philadelphia, USA.

4. Harkness, J. E. and J. E. Wagner. 1995. The biology and medicine of rabbits and rodents. 4th ed., Philadelphia, Lea and Febiger.

5. Heneweer, M., R. Houtman, J. Poortman, M. Grot and A. Peijmenburg. 2007. Estrogenic effect in the immature rat uterus after diatery exposure to ethinyl estradiol and zeoralenoe using a system biology approach. Toxicol. Scien., 99 (1): 303-314.

6. James,G. F., C. A. Lynn, M. L. Frankline and W. Q. Fred. 2002. Laboratory animal medicine. 2nd ed., Academic Press, London, New York.

7. Khalifa,W. H. 2006. Effect of feeding program on reproductive and productive performance of rabbits. M.V.Sc., Thesis, Fac. Agric., Cairo University.

8. Mabrouk, E. A., H. A. Mansour and A. H. El-Qnwar. 1993. Effects of estradiol administration on hepatorenal functions in male rats. Vet.Med.J.Giza, 41 (1): 2932.

9. Marshall, J. W. 1988. Clinical chemistry. J.B.Lippincott Company, Philadelphia, Gower Medical Publishing, London, New York.

10. Mcguire, M., W. R. Butter and K. M. Rasmussen. 1992. Chronic food restriction amplifies the effect of lactation on the duration of post partum anestrous in rats. J.Nut., 122: 1726-1730.

11. Srivastava, S. R., K. B. Govid, S. Chondom and M. M. Singh. 2007. Pregnancy interceptive activity of the roots of colotropis gigantean linn in rats. Contraception, 75 (4): 318-322.

12. Turgeon, J. I. 1979. Estradiol luteinizing relationship during the proestrus gonadotrophin. Surg.Endoct., 105 (3): 131-136. 
13. Wallace, J. M., S. John and R. P. Aitken. 2004. Maternal growth hormone treatment from day 35 to 80 of gestation alters nutrient partitioning in favour of uteroplacental growth in the overnourished adolescent sheep. Biology Reprod., 70: 1277-1285.

14. Williams, K., J. J. Fisher, K. J. Tuner, P. T. Sounders and R. M. Sharpe. 2001. Relationship between expression of sex steroid receptors and structure of the seminal vesicles after neonatal treatment of rats with potent or weak estrogens. Environ. Health Perspective, 109 (12): 1227-1235. 


\section{محاولات مبائية لزيادة إنتاج الذكور وتحسين مظاهر النمو

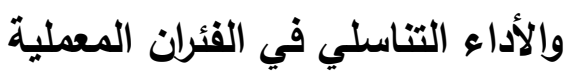

معرة بحوث الأمصال واللقاحات البيطرية - مركز البحوث الزراعية - وزارة الزراعة - الدقى - الجيزة

أجريت هذه الدراسة لإنتيان تأثير الإثثيل إستراديول على الأداء التناسلي والإنتاجي للفئران

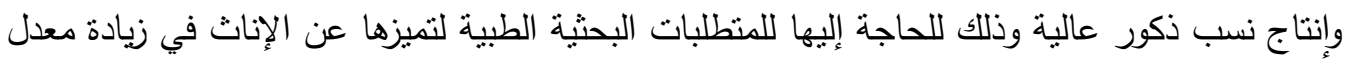

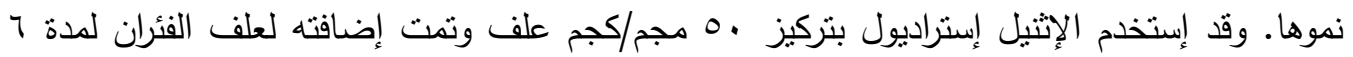

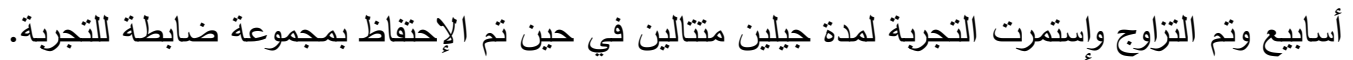

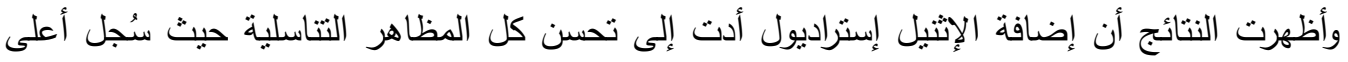

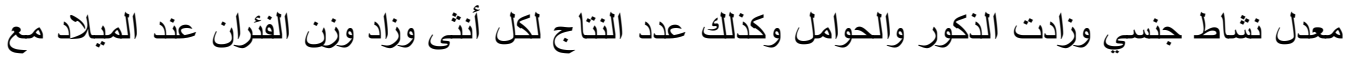

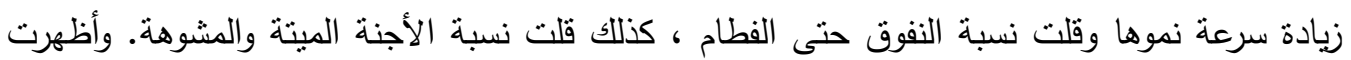

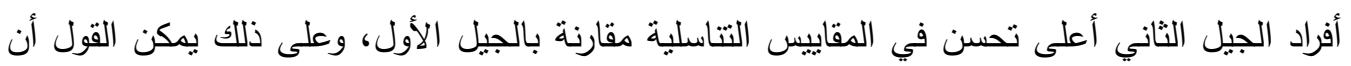
إضافة الإثيل إستراديول لعلائق الفئران المعطلية يحسن الكفاءة التناسلية ومظاهر النمو. 